\title{
DAYA SAING EKSPOR PALA INDONESIA DI PASAR INTERNASIONAL
}

\section{Indonesia's Most Export Competitiveness In The International Market}

\author{
Asrol dan Heriyanto \\ Program Studi Agribisnis, Fakultas Pertanian Universitas Islam Riau \\ Jl. Kaharuddin Nasution No. 113 Pekanbaru. 28284 \\ Telp: 0761-674681; Fax: 0761-674681 \\ [Diterima Juni 2017, Disetujui Agustus 2017
}

\begin{abstract}
Indonesia is one of the largest producing and exporting countries for nutmeg commodities in the world market. Indonesia as a nutmeg exporting country is a country that imports nutmeg products. Nutmeg is one of Indonesia's leading spice export commodities on the world market. Based on the description in general, this study aims to analyze the competitiveness of Indonesian nutmeg in the world market. Specifically, this study aims to analyze the export position of nutmeg and the competitiveness of Indonesian nutmeg in the international market. The power used in this study is secondary time series data from 2007-2016. To answer the research objectives, it was analyzed using the Trade Specialization Index (ISP), Revealed Comparative Advantage (RCA) and Constant Market Share (CMS). Based on the results of the study indicate that for the position of Indonesian nutmeg exports on the world market, the average value of Indonesian ISPs on the world market from 2007-2016 was 0.988. This value indicates that the position or stage of Indonesian nutmeg export is at the maturity stage with an indicator value (0.81-1.00). Furthermore, the competitiveness of the results of the average Indonesian nutmeg RCA value on the international market which is calculated from 2007-2016 reached 19,554 because the value of Indonesian nutmeg RCA is greater than one, so Indonesia has a strong competitiveness in the export of nutmeg in the world and tends to be a country exporter rather than importer. For the CMS value of Indonesian nutmegs in the last five years period is negative on the standard growth, composition effects, and market distribution effects but the positive value on the effect of competitiveness.
\end{abstract}

Key Words: Nutmeg, Export, Competitiveness, International

\begin{abstract}
ABSTRAK
Indonesia merupakan salah satu negara produsen dan pengekspor terbesar untuk komoditas pala di pasar dunia. Indonesia sebagai negara pengekspor pala sekaligus merupakan negara pengimpor produk pala. Pala merupakan salah satu komoditas rempah ekspor unggulan Indonesia di pasar dunia. Berdasarkan uraian tersebut secara umum penelitian ini bertujuan untuk menganalisis daya saing pala Indonesia di pasar dunia. Adapun secara spesifik penelitian ini bertujuan untuk menganalisis posisi ekspor pala dan kemampuan daya saing pala Indonesia di pasar internsional. Daya yang digunakan dalam penelitian ini adalah data sekunder time series dari tahun 2007-2016. Untuk menjawab tujuan penelitian dianalisis menggunakan Indeks Spesialisasi Perdagangan (ISP), Revealed Comparative Advantage (RCA) dan Constant Market Share (CMS). Berdasarkan dari hasil penelitian menunjukan bahwa bahwa Untuk posisi ekspor pala Indonesia di pasar dunia, nilai rata-rata ISP Indonesia di pasar dunia dari tahun 2007-2016 sebesar 0,988. Nilai ini menunjukan bahwa posisi atau tahapan ekspor pala Indonesia berada pada tahap kematangan dengan nilai indikator $(0,81-1,00)$. Selanjutnya kemampuan daya saing dari hasil nilai rata-rata RCA pala Indonesia di pasar internasional yang dihitung dari tahun 2007-2016 mencapai 19,554 karena nilai RCA pala Indonesia lebih besar dari satu maka Indonesia memiliki daya saing yang kuat dalam ekspor pala di dunia dan cendrung menjadi negara pengekspor daripada pengimpor. Untuk nilai CMS pala Indonesia pada priode lima tahun terakhir bernilai negatif pada pertumbuhan setandar, efek komposisi dan efek distribusi pasar namun bernilai positif pada efek daya saing.
\end{abstract}

Kata Kunci: Pala ,Ekspor, Daya saing, Internasional 


\section{PENDAHULUAN}

Indonesia merupakan negara agraris yang memiliki potensi yang sangat besar di dalam sektor pertanian (Heriyanto,2017, 2016;:Wahyudy,2016;Darus,2017).Dari berbagai banyak komoditas pertanian yang diekspor Indonesia di pasar dunia salah satunya adalah buah pala yang merupakan tanaman rempah yang menjadi salah satu unggulan Indonesia. Indonesia merupakan salah satu negara yang menghasilkan rempah-rempah terbaik di dunia. Selain di Indonesia pala juga merupakan komoditi penting di Eropa, bukan hanya sebagai bumbu masakan tapi juga sebagai bahan dasar pembuatan produk kosmetik dan kesehatan (Badan Pusat Statistik, 2015).

Indonesia sebagai negara pengekspor pala sekaligus merupakan negara pengimpor produk pala. Hal ini disebabkan masih kurangnya terdistribusi dengan baik pala dari pusat produksi pala Indonesia menuju daerah yang tidak memproduksi pala. Sehingga Indonesia mendistribusikan pala ketempat non produksi pala dengan biaya dan resiko yang lebih besar maka lebih baik Indonesia mengimpor pala dari negara tetangga.

Seiring dengan meningkatnya permintaan pala dunia untuk memenuhi kebutuhan dari berbagai negara yang tidak mampu mencukupi kebutuhan dalam negeri ataupun tidak memproduksi sama sekali, maka negara produsen terus giat melakukan ekspor pala. Adapun perkembangan volume ekspor pala Indonesia dan negara pesaing ke dunia tahun 2007-2016 dapat dilihat pada Gambar 1. Pada Gambar 1 dapat dilihat dalam kurun waktu sepuluh tahun terakhir perkembangan volume ekspor pala Indonesia dan negara pesaing terjadi secara berfluktuatif. Adapun volume ekspor pala Indonesia terbesar terjadi pada tahun 2015 yakni dengan volume sebesar 13.986 ton. Hal ini yang menunjukkan harus adanya perhatian pemerintah terhadap produksi pala Indonesia agar volume ekspor pala Indonesia menjadi membaik.

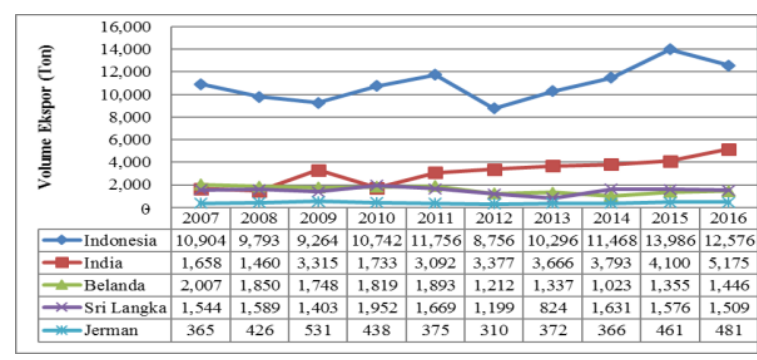

Sumber : UN COMTRADE, (diolah)

Gambar 1. Perkembangan Volume Ekspor Pala Indonesia dan Negara Pesaing Tahun 2007-2016.

Jika dilihat dari negara-negara pesaing maka yang menempati posisi kedua adalah India dengan nilai ekspor terbesar terjadi pada tahun 2016 yakni mencapai 5.175 Ton dan disusul Srilangka, Belanda dan Jerman pada posisi tiga empat dan lima (Uncomtrade, 2017).

Selain dilihat dari volume ekspor pala Indonesia dan negara pesaing nilai ekspor juga berpengaruh terhadap pendapatan yang diterima dari ekspor pala per tonnya. Adapun nilai ekspor pala Indonesia dan negara pesaing tahun 20072016 dapat dilihat pada Gambar di bawah.

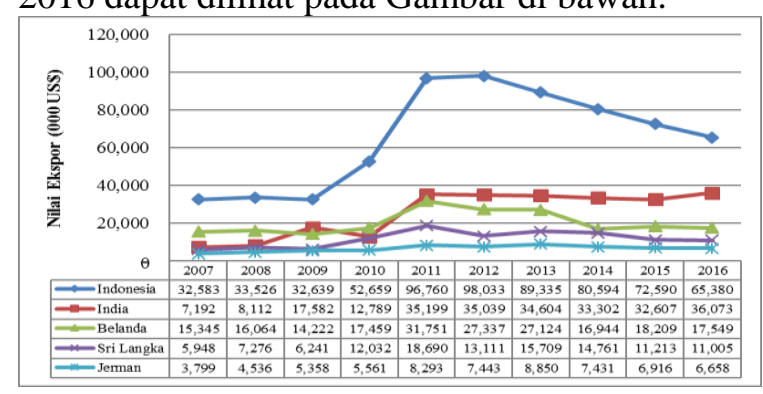

Sumber : UN COMTRADE, (diolah)

Gambar 2. Perkembangan Nilai Ekspor Pala Indonesia dan Negara Pesaing Tahun 2007-2016.

Berdasarkan Gambar 2, dapat disimpulkan bahwa nilai ekspor Indonesia dan negara pesaing terjadi secara berfluktuatif dan jika dibandingkan volume ekspor maka nilai ekspor tidak seirama karena terjadinya perubahan faktor-faktor yang mempengaruhi nilai ekspor pala itu sendiri (Kuncoro, 2008). Untuk nilai ekspor terbesar pala Indonesia terjadi pada tahun 2012 yakni mencapai 98.033.000 US\$.

Berdasarkan uraian diatas pada latar belakang, secara umum penelitian ini bertujuan 
untuk menganalisi daya saing ekspor pala Indonesia di pasar internasional adapaun tujuan secara spesifik yaitu: menganalisis posisi dan daya saing ekspor pala Indonesia di pasar internasional.

\section{METODE PENELITIAN}

Penelitian ini menggunakan data yang data sekunder yaitu berupa data time series selama 10 tahun yaitu tahun 2007 - 2016. Data Sekunder yang dikumpulkan untuk penelitian ini yaitu data statistik: data produksi, data luas lahan, data ekspor dan impor pala Indonesia dan negara pesain yaitu India, Belanda, Srilanka dan Jerman. Data ini diperoleh dari instansi terkait, antara lain: Badan Pusat Statistik (BPS), International Trade Center yang ditelusuri melalui jaringan internet, United Nation Trade, Direktorat Jendral Perkebunan Republik Indonesia, Badan Pengawas Perdagangan Berjangka Komoditi, dan Food and Agriculture Organization (FAO), Pusat data dan Informasi Industri Kementerian Perindustrian RI

\section{Analisis Data}

\section{Indeks Spesialisasi Perdagangan}

Untuk menganalisis posisi atau tahapan ekspor adalah menggunakan ISP. ISP merupakan ukuran yang digunakan untuk menganalisis posisi atau tahapan perkembangan suatu produk sehingga dapat dilihat kecenderungan suatu negara sebagai eksportir atau importir. ISP akan mengidentfikasi tingkat pertumbuhan suatu produk dalam perdagangan kedalam 5 tahap sebagai berikut ((Adi, Putra, I, Ketut \& Aswitari, Luh, 2015; Salvatore, 1997; Tambunan, 2004):

Indeks Spesialisasi Perdagangan (ISP) digunakan untuk menganalisis posisi atau tahapan perkembangan suatu produk. ISP ini dapat menggambarkan apakah suatu jenis produk Indonesia cenderung menjadi negara eksportir atau importir. Secara matematika, ISP dapat dirumuskan sebagai berikut:

$$
I S P=\frac{\left(X_{i t}-M_{i t}\right)}{\left(X_{i t}+M_{i t}\right)}
$$

Keterangan:

ISP = Indeks Spesialisasi Perdagangan

Xit $=$ Nilai ekspor komoditi Pala

Indonesia pada tahun $\mathrm{t}$ (US\$)

Mit = Nilai impor komoditi Pala

Indonesia pada tahun $\mathrm{t}$ (US\$)
Dalam menganalisis Daya Saing Pala rumusnya adalah sebagai berikut:

$\mathrm{ISP}=\frac{\text { Nilai ekspor PALA } \mathrm{t}-\text { Nilai Impor PALA } \mathrm{t}}{\text { Nilai ekspor PALA } \mathrm{t}+\text { Nilai Impor PALA } \mathrm{t}}$

Nilai ISP ini mempunyai kisaran antara -1 sampai dengan +1 . Jika nilanya positif diatas 0 sampai 1, maka komoditi bersangkutan dikatakan mempunyai daya saing yang kuat atau negara yang bersangkutan cenderung sebagai pengekspor dari komoditi tersebut (penawaran domestik lebih besar daripada permintaan domestik). Sebaliknya, daya saingnya rendah atau cenderung sebagai pengimpor (penawaran domestik lebih kecil dari permintaan domestik), jika nilainya negatif dibawah 0 hingga -1 . Kalau indeksnya naik berati daya saingnya meningkat, dan begitu juga sebaliknya.

Indeks ISP tersebut juga dapat digunakan untuk mengidentifikasi tingkat pertumbuhan suatu komoditi dalam perdagangan yang terbagi ke dalam lima tahap sebagai berikut:

1. Tahap Pengenalan

Ketika suatu industri (forerunner) disuatu negara (sebut $\mathrm{X}$ ) mengekspor produkproduk baru dan industri pendatang belakangan (latercomer) di negara Y impor produk-produk tersebut. Dalam tahap ini, nilai indeks ISP dari industri latercomer ini adalah -1,00 sampai 0,50 .

2. Tahap Subtitusi Impor

Nilai indeks ISP naik antara - 0,51 sampai 0,00. Pada tahap ini, industri di negara $Y$ menunjukkan daya saing yang sangat rendah, dikarenakan tingkat produksinya tidak cukup tinggi untuk mencapai skala ekonominya. Industri tersebut mengekspor produk-produk dengan kualitas yang kurang bagus dan produksi dalam negeri masih lebih kecil daripada permintaan dalam negeri. Dengan kata lain, untuk komoditi tersebut, pada tahap ini negara $Y$ lebih banyak mengimpor daripada mengekspor.

3. Tahap Pertumbuhan

Nilai indeks ISP naik antara 0,01 sampai 0,80 . Pada tahap ini industri di negara $Y$ melakukan produksi dalam skala besar dan mulai meningkatkan ekspornya. Di pasar domestik, penawaran untuk komoditi tersebut lebih besar dar pada permintaan.

4. Tahap Kematangan 
Nilai indeks ISP berada pada kisaran 0,81 sampai 1,00. Pada tahap ini produk yang bersangkutan sudah pada tahap standardisasi menyangkut teknologi yang dikandungnya. Pada tahap ini negara Y merupakan negara net exporter.

5. Tahap kembali mengimpor

Nilai indeks ISP kembali menurun antara 1,00 sampai 0,00. Pada tahap ini industri di negara $\mathrm{Y}$ kalah bersaing di pasar domestiknya dengan industri dari negara $X$, dan produksi dalam negeri lebih sedikit dari permintaan dalam negeri.

\section{Analisis Kemampuan Daya Saing Pala Indonesia Di Pasar Dunia}

\section{a. Analisis Revealed Comparative}

Advantage (RCA)

Keunggulan komparatif dapat diukur dengan menggunakan alat analisis Revealed Comparative Advantage (RCA) digunakan mengukur tingkat daya saing. Banyak kajian yang mengukur tingkat daya saing/keunggulan dari suatu jenis produk atau sekelompok produk di pasar ekspor (Adi, Putra, I, Ketut \& Aswitari, Luh, 2015; Anggit, 2012; Fitriana, 2014a, 2014b; Hagi, 2014; Hasibuan A.M, 2011; Kania, 2012; Kusuma, Rahma \& Firdaus, 2015; Ogi, Suparsa \& Martini, Dewi, 2016; Prasetio \& Swara, I Wayan, 2015; Rajagukguk, 2009; Ratna Sari \& Tety, 2017; Satryana, Made \& Karmini, 2016; Setiawan \& Hartono, Slamet Suryantini, 2014; Uncomtrade, 2017; Wardanu \& Muh, 2009; Zuhdi \& Suharno, 2015). Dasar pemikiran yang melandasi indeks ini adalah bahwa kinerja ekspor suatu Negara sangat ditentukan tingkat daya saing relatifnya terhadap produk serupa buatan Negara lain, tentu dengan asumsi cateris paribus (hubungan operasional antara harga dan kuantitas suatu barang) yakni nilai mata uang yang diperdagangkan bahwa faktor-faktor lain yang mempengaruhi pertumbuhan ekspor tetap tidak berubah.

Indeks ini yang paling sering digunakan dalam studi-studi empiris untuk mengukur tingkat daya saing/keunggulan dari suatu jenis produk atau sekelompok produk di pasar ekspor. Dengan kata lain indeks RCA menunjukkan tingkat daya saing dari suatu daerah dalam suatu komoditas terhadap dunia. Adapun cara penghitungan RCA menurut (Salvatore, 1997; Tambunan, 2004) adalah sebagai berikut:

$$
R C A=\frac{\left(\frac{X O i}{X t i}\right)}{\left(\frac{X W O i}{X W t}\right)}
$$

Keterangan:

$$
\begin{aligned}
& \mathrm{RCA}=\text { Revealed Comparative } \\
& \text { Advantage } \\
& \text { XOi = Nilai ekspor Pala Indonesia } \\
& \text { (US\$) } \\
& \text { XWOi }=\text { Nilai ekspor Pala dunia (US\$) } \\
& \mathrm{Xti}=\text { Total nilai ekspor Indonesia } \\
& \text { (US\$) } \\
& \mathrm{XWt}=\text { Total nilai ekspor dunia }
\end{aligned}
$$

(US\$)

Dalam menganalisis Daya Saing Pala maka rumusnya adalah sebagai berikut:

$$
R C A=\frac{\left(\frac{\text { Nilai EksporPALA Indonesia }}{\text { Total Nilai Seluruh Ekspor Indonesia }}\right)}{\left(\frac{\text { Nilai Ekspor PALA Dunia }}{\text { Total Nilai Seluruh Ekspor Dunia }}\right)}
$$

Nilai rasio RCA di bawah satu (1) menunjukkan posisi yang tidak menguntungkan dalam ekspor (relative disadvantage), artinya komoditas tersebut mempunyai daya saing yang lemah. Sedangkan sebaliknya RCA di atas satu (1) menunjukkan adanya keuntungan relatif (relative advantage), artinya komoditas yang bersangkutan mempunyai daya saing yang relatif lebih kuat dibanding komoditas tertentu dengan produk yang sama di negara lain. Jika RCA sama dengan satu (1) berarti daya saing komoditas tersebut sebanding dengan daya saing komoditas yang sama dengan Negara-negara pengekspor dunia (Da, 2014; Nopirin, 1999; Salvatore, 1997; Tambunan, 2004)

\section{b. Analisis Constant Market Share (CMS)}

Untuk menentukan efek yang paling signifikan dalam memengaruhi daya saing suatu komoditi maka digunakanlah Analisis Constant Market Share atau analisis pangsa pasar konstan digunakan untuk mengukur dinamika tingkat daya saing suatu industri dari suatu negara dan efek yang paling memengaruhinya.

Untuk menganalisis tingkat daya saing Indonesia pertahun dan distribusi pertumbuhannya berdasarkan 4 efek digunakan metode CMSA secara matematis dapat dirumukan sebagai berikut (Salvatore, 1997; Tambunan, 2004): Pertumbuhan Standar : 


$$
\frac{E\left({ }_{t}\right)-E\left(_{t-1}\right)}{E\left({ }_{t-1}\right)}=r
$$

Pengaruh Komposisi Komoditas:

$+\frac{\sum_{t}\left(r_{t}-r\right) E_{t(t-1)}}{E_{(t-1)}}$

Pengaruh Distribusi Pasar:

$$
+\frac{\sum_{t}\left(r_{t}-r\right) E_{t(t-1)}}{E_{(t-1)}}
$$

Daya Saing:

$$
\begin{aligned}
& +\frac{\sum_{t} \sum_{j}\left(E_{t j(t)}-E_{t j}\left({ }_{t-1}\right)-r_{t j} E_{t j}\left({ }_{t-1}\right)\right)}{E\left(\left(_{t-1}\right)\right.} \\
& * r i \frac{E_{(t) t}-E_{(t-1) t}}{E\left({ }_{t-1}\right) t} \\
& * * r i j=\frac{E_{t j}(t)-E_{t j}\left({ }_{t-1}\right)}{E_{t j}\left({ }_{t-1}\right)}
\end{aligned}
$$

dimana:

$\mathrm{W}(\mathrm{t}) \quad=$ nilai ekspor Dunia untuk semua komoditi tahun $\mathrm{t}$ (US\$)

$\mathrm{W}(\mathrm{t}-1)=$ nilai total ekspor Dunia untuk semua komoditi tahun $\mathrm{t}-1$ (US\$)

$\mathrm{r} \quad=$ pertumbuhan standar (semua komoditi) (US\$)

ri $\quad=$ pertumbuhan standar komoditi Pala (US\$)

rij = pertumbuhan standar komoditi Pala di negara $\mathrm{j}$ (US\$)

Ei $(\mathrm{t})=$ Ekspor komoditi Pala Indonesia tahun $\mathrm{t}$ (US\$)

Ei $(\mathrm{t}-1)$ = Ekspor komoditi Pala Indonesia tahun $\mathrm{t}-1$ (US\$)

Eij $(\mathrm{t})=$ Ekspor komoditi Pala dari negara Indonesia ke negara tujuan pada tahun $\mathrm{t}$ (US\$)

Eij $(\mathrm{t}-1)=$ Ekspor komoditi Pala dari negara Indonesia ke negara tujuan pada tahun $\mathrm{t}-1$ (US\$)

Formulasi pengukuran daya saing dengan Constant Market Share (CMS) menjelaskan faktor yang memengaruhi ekspor suatu negara lebih tinggi sama atau lebih rendah dari prtumbuhan ekspor dunia. Devisiasi negatif antara pertumbuhan ekspor suatu negara dengan pertumbuhan standar dapat dikarenakan empat hal yaitu, pertumbuhan permintaan memang melambat, masalah komposisi komoditi yang diminati atau tidak diminati oleh pasar, masalah distribusi pasar duia dari negara eksportir dan masalah daya asing dalam harga dan kualitas. Keempat komponen ini dapat dianalisis dengan :
1. Efek pertumbuhan standar menggambarkan pertumbuhan ekspor suatu negara disebabkan oleh peningkatan impor dunia. Jika efek pertumbuhan standar bernilai positif, maka terjadi peningkatan ekspor pada negara eksportir yang disebabkan oleh pertumbuhan impor dunia. Sebaliknya jika bernilai negatif, maka terjadi kemunduran ekspor di negara eksportir karena penurunan impor di negara importir atau dunia.

2. Efek komposisi terkait dengan minat pasar internasional terhadap barang yang bersangkutan. Jika nilai dari efek komposisi komoditi pala berdasarkan analisis CMS bernilai positif, maka mengindikasikan bahwa komoditi pala cenderung diminati di pasar internasional dibanding jenis komoditi lainnya dan nilai ekspornya cenderung meningkat dibanding total ekspor suatu negara. Sebaliknya jika efek komposisi bernilai negatif maka komoditi pala cendrung kurang diminati oleh pasar dunia dan nilai ekspornya cenderung lebih kecil dibandingkan total ekspor untuk seluruh komoditi.

3. Efek distribusi pasar menunjukkan pertumbuhan ekspor pala dipengaruhi oleh kemampuan suatu negara dalam memasarkan komoditi pala ke pasar yang memiliki permintaan yang tinggi. Apabila nilai efek distribusi positif, maka negara tersebut telah memasarkan komoditi pala di negara yang memiliki permintaan yang tinggi. Sedangkan jika nilai efek distribusi bernilai negatif, maka suatu negara dinilai belum memasarkan komoditi pala tersebut ke negara yang memiliki permintaan tinggi.

Efek daya saing yang bernialai positif menggambarkan daya saing ekspor pala suatu negara yang tidak diakibatkan oleh efek pertumbuhan standar, efek komposisi dan distribusi pasar, akan tetapi karena ada daya saing akibat keunggulan mutu produk atau harga yang lebih baik, sedangkan apabila efek daya saing berinilai negatif mengindikasikan daya saing pala suatu negara lemah dilihat dari aspek mutu dan harga.

\section{HASIL DAN PEMBAHASAN Posisi Pala Indonesia di Pasar Dunia} Indeks Spesialisasi Perdagangan (ISP) digunakan untuk menganalisis posisi atau tahapan perkembangan suatu komoditas dalam 
perdagangan. Nilai indeks ini mempunyai kisaran antara -1 sampai dengan +1 . Jika nilanya positif diatas 0 sampai 1, negara yang bersangkutan cenderung sebagai pengekspor dari komoditi tersebut (suplai domestik lebih besar daripada permintaan domestik). Sebaliknya, jika suatu negara cenderung sebagai pengimpor (suplai domestik lebih kecil dari permintaan domestik), jika nilainya negatif dibawah 0 hingga -1 .

Perhitungan ISP menggunakan nilai ekspor dan nilai impor pala. Adapun nilai ekspor dan nilai impor pala Indonesia dan negara pesaing sepuluh tahun terakhir dapat dilihat pada Tabel berikut.

Tabel 1. Nilai Ekspor dan Impor Pala Indonesia dan Negara Pesaing di Pasar Dunia Tahun 2007-2016

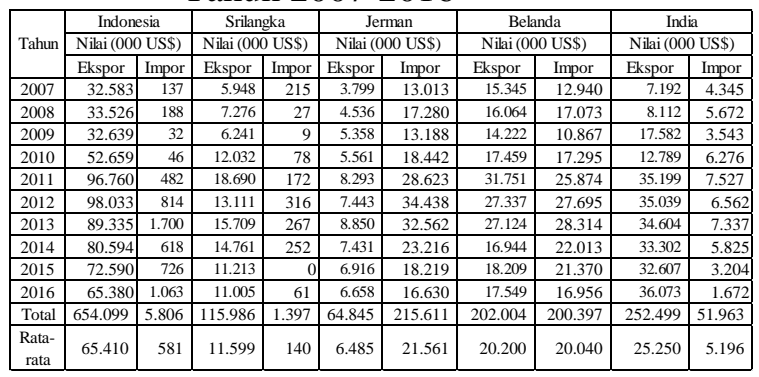

Sumber: UN COMTRADE (diolah)

Berdasarkan data Tabel di atas dapat dilihat bahwa nilai ekspor dan nilai impor Indonesia dan negara pesaing berfluktuatif. Namun negara yang nilai ekspornya lebih besar dari nilai impor adalah Indonesia, Srilangka dan India. Untuk Indonesia Nilai ekspor terbesar terjadi pada tahun 2012 yakni mencapai 140 juta US\$, sedangkan nilai impor terbesar terjadi pada tahun 2013 yakni mencapai 1,7 juta US\$ (Uncomtrade, 2017). Maka dengan data tersebut dapat menghasilkan nilai ISP dengan rumus yang sudah tertera pada bab tiga, untuk lebih jelas berada dimana tahapan ekspor pala Indonesia dan negara pesaing di pasar dunia dapat dilihat pada Gambar berikut.

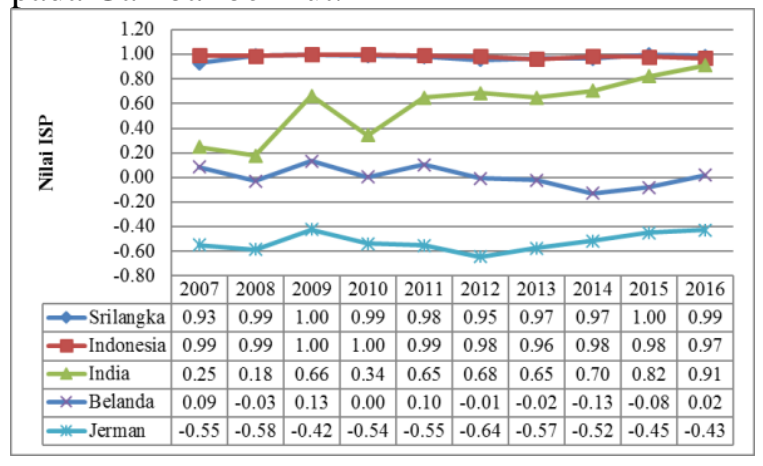

Gambar 3. Nilai ISP Pala Indonesia dan Negara Pesaing Tahun 2012-2016.

Dari Gambar diatas, terlihat nilai ISP pala Indonesia secara umum per tahunnya berada pada kisaran dari 0,90 sampai 1,00. Ini berarti bahwa pala Indonesia sudah berada pada tahap kematangan dan standardisasi menyangkut kualitas yang dimilikinya. Pala Indonesia juga mempunyai keunggulan yang kuat dengan kecenderungannya sebagai pengekspor dari produk tersebut (penawaran domestik lebih besar daripada permintaan domestik), yang juga merupakan negara net exporter (keunggulan dalam mengekspor).

Jika dilihat dari nilai ISP negara pesaing pada tahun 2016 maka Srilangka dan India yang memiliki posisi ekopor yang berada pada tahap kematangan hal ini dikarenakan Srilangka dan India memiliki nilai ISP yang positif yakni 0,99 dan 0,91 . Sementara itu Belanda dan Jerman berada pada tahap subsitusi Impor yakni dengan nilai 0,02 dan belanda berada pada tahap pengenalan dengan nilai $-0,43$.

\section{Kemempuan Daya Saing Pala Indonesia di Pasar Internasional}

Daya saing pala Indonesia dapat diukur dari keunggulan komparatifnya. Keunggulan komparatif dari pala Indonesia dapat dianalisis menggunakan Revealed Comparative Advantage $(R C A)$ yang bertujuan untuk membandingkan posisi daya saing Indonesia dengan negara eksportir lainnya pada komoditas pala di pasar dunia. Jika RCA>1 (lebih dari satu), menunjukkan pangsa komoditi pala dalam total ekspor negara lebih besar dari pangsa komoditi yang bersangkutan di dalam ekspor dunia. Semakin besar nilai RCA menunjukkan semakin kuat daya saing yang dimiliki. Negara-negara yang dibandingkan dengan Indonesia dalam analisis RCA adalah empat negara eksportir dengan nilai ekspor terbesar yang menguasai pangsa pasar pala dunia seperti India, Belanda, Sri Langka dan Jerman. Untuk menghasilkan nilai RCA pala maka data yang diperlukan adalah nilai ekspor pala negara ke pasar dunia dan nilai ekspor negara seluruh komoditas yang diekspor ke pasar dunia. Adapun data nilai ekspor pala Indonesia dan negara pesaing ke pasar dunia dapat dilihat pada Lampiran 10. 
Dari data pada Lampiran 10 maka menunjukan bahwa baik nilai ekspor pala maupun total nilai ekspor seluruh komoditi dunia, Indonesia dan negara pesaing berflutuatif. Dengan data yang tertera pada Lampiran 10 dapat dihasilkan nilai RCA pala Indonesia dan negara pesaing untuk kurun waktu mulai tahun 2007 sapai dengan 2016. Untuk lebih jelas perhitungan nilai RCA dapat dilihat pada Gambar di bawah.

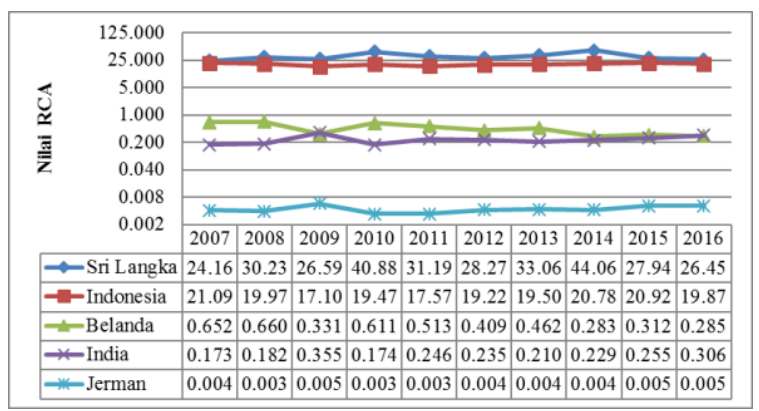

Sumber : data diolah

Gambar 4. Nilai RCA Pala Indonesia dan Negara Pesaing Tahun 2012-2016.

Dari Gambar diatas, nilai RCA pala Indonesia yang lebih dari satu, ini menunjukkan bahwa pala Indonesia memiliki daya saing yang kuat dalam pasar perdagangan dunia, ditunjukkan dengan nilai RCA sepuluh tahun terakhir berkisar antara 17,103 sampai 21,096. Sehingga disarankan untuk terus dikembangkan dengan melakukan spesialisasi pada produk tersebut.

Jika dibandingkan dengan negara pesaing perhitungan nilai RCA pada tahun 20072016 dari lima negara dengan nilai ekspor pala terbesar di dunia ternyata negara yang memiliki daya saing pala di pasar dunia hanya Indonesia dan Srilangka dengan nilai rata-rata Indonesia sebesar 19,554 dan Sri Langka sebesar 31,289 sedangkan tiga negara lain tidak memiliki daya saing. Hal ini dibuktikan bahwa nilai RCA Indonesia dan Sri Langka lebih dari satu sedangkan nilai RCA India, Belanda dan Jerman kurang dari satu.

Kondisi tersebut di atas juga menunjukkan bahwa Indonesia telah berhasil memanfaatkan peluang dalam peningkatan ekspor dengan adanya pertumbuhan di pasar dunia.

Analisis Constant Market Share (CMS) merupakan metode untuk menganalisis pola perdagangan serta tren perdagangan yang kemudian dikembangkan untuk tujuan formulasi kebijakan perekonomian. Analisis CMS digunakan berdasarkan pemahaman bahwa laju pertumbuhan ekspor suatu negara dapat lebih rendah atau tinggi dari laju pertumbuhan ekspor dunia. Pertumbuhan ekspor sebuah negara dapat diuraikan dalam tiga efek, yaitu efek komposisi komoditas, efek distribusi pasar dan efek daya saing. Negara pesaing yang digunakan dalam penelitian ini yaitu India, Belanda, Sri Langka dan Jerman penetapan negara ini berdasarkan nilai ekspor tertinggi pala ke dunia. Untuk lebih jelas dapat dilihat pada Tabel di bawah.

Tabel 2. Nilai Constant Market Share (CMS) Pala Indonesia dan Negara Pesaing Tahun 2007-2016.

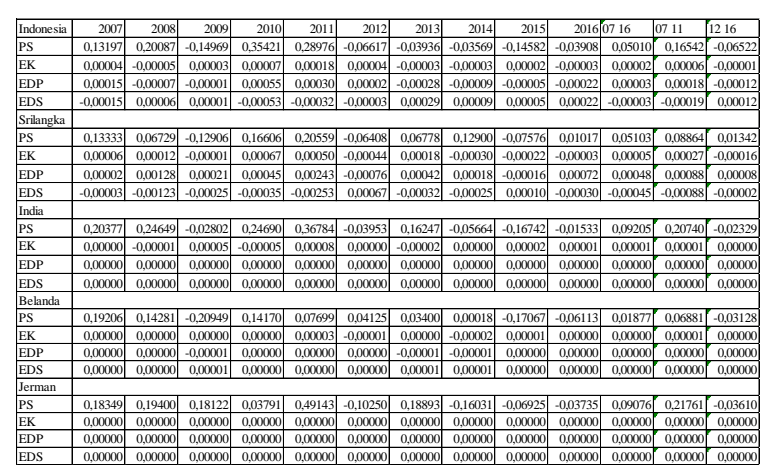

Sumber: data diolah

Keterangan: PS = Pertumbuhan standar $\mathrm{EK}=$ Efek Komposisi $\mathrm{EDP}=$ Efek Distribusi pasar EDS = Efek Daya Saing

Berdasarkan Tabel di atas maka dapat ditarik kesimpulan bahwa nilai dari pertumbuhan standar, efek komposisi, efek distribusi pasar dan efek daya saing pala Indonesia mulai tahun 20072016 berfluktuatif. Pada priode tahun 2012 sampai 2016 pertumbuhan standar pala Indonesia menunjukan nilai negatif yakni (0,06522) hal ini menunjukkan bahwa pala Indonesia mengalami kemunduran ekspor di pasar dunia sebesar nilai tersebut. Untuk efek komposisi pala Indonesia menunjukan nilai negatif yakni $(-0,00001)$ hal ini menunjukan bahwa pala Indonesia kurang diminati dan cendrung nilai ekspor lebih kecil dibandingkan dengan total nilai ekspor untuk seluruh komoditi yang diekspor Indoneisa. Sedangkan untuk efek daya saing pala Indonesia menunjukan nilai positif yakni $(0,00012)$ hal ini menunjukan 
bahwa adanya keunggulan pala Indonesia dari segi mutu produk dan harga yang lebih baik.

Jika dibandingkan dengan negara pesaing maka pada periode tahun tahun 20122016 maka Indonesia masih memiliki nilai yang lebih baik dari ke empat negara pesaing lainnya terutama pada efek daya saing.

\section{KESIMPULAN}

1. Posisi ekspor pala Indonesia dapat dilihat dari nilai rata-rata ISP pala Indonesia. Menunjukan bahwa posisi ekspor pala Indonesia berada pada tahap kematangan dan cenderung menjadi negara pengekspor, serta supply domestic pala lebih besar dari pada demand domestic pala Indonesia.

2. Daya saing komoditas ekspor pala Indonesia memiliki daya saing yang kuat di pasar dunia karena nilai RCA lebih dari 1. Sedangkan pada nilai CMS meskipun rata-rata pada pertumbuhan setandar, efek komposisi dan efek distribusi pasar masih berada pada nilai yang negatif namun pada efek daya saing pala Indonesia berada pada nilai yang positif yakni dengan nilai rata-rata dari tahun 2012-2016 sebesar 0,000123 yang berarti pala Indonesia masih memiliki kemampuan dalam segi mutu dan harga yang baik.

\section{DAFTAR PUSTAKA}

Adi, Putra, I, Ketut, B. M., \& Aswitari, Luh, P. (2015). Analisis Daya Saing Dan FaktorFaktor Yang Mempengaruhi Ekspor Kayu Lapis Indonesia Ke Jepang. E-Jurnal Ekonomi Pembangunan Universitas Udayana, 4(6), 608-745.

Anggit, R. (2012). Analisis Daya Saing Crude Palm Oil (CPO) Indonesia di Pasar Internasional. Jurnal Fakultas Pertanian, Universitas UPN “Veteran," 9(1), 125133.

Badan Pusat Statistik. (2015). Statistik Indonesia. Jakarta: Badan Pusat Statistik Indonesia.

Da, H. (2014). Impact of Country-Level Factorson Export Competitiveness Of Agriculture Industry From Emerging Markets. Competitiveness Review., 24(5), 393-413. https://doi.org/10.1108/CR-012012-0002 2014
Darus, H. A. W. (2017). Analysis Of Human Resources Work In Production Activity Hydroponic Vegetables Commodity (Case Study: Technical Implementation Unit Of Agro Garden. Proceedng ICoSET, 8, 254.

Fitriana, N. (2014a). Analisis Daya Saing Ekspor Biji Kakao (Cocoa Beans) Indonesia di Pasar Internasional. Skripsi Fakultas Pertanian, Universitas Riau, Pekanbaru. (Tidak dipublikasikan).

Fitriana, N. (2014b). Analisis Daya Saing Ekspor Biji Kakao (Cocoa Beans) Indonesia di Pasar Internasional.

Hagi. (2014). Analisis Daya Saing Ekspor Minyak Sawit Indonesia dan Malaysia di Pasar Internasional.

Wahyudy, H. A., Bahri, S., \& Tibrani, T. (2016). Optimasi USAha Budidaya Ikan Air Tawar Pada Keramba Jaring Apung Di Waduk Plta Koto Panjang Kabupaten Kampar Provinsi Riau. Jurnal Agribisnis, 18(1), 1225.

Hasibuan A.M. (2011). Analisisi Kinerja dan Daya Saing Perdagangan Biji Kakao dan Produk Kakao Olahan Indonesia di Pasar Internasional. Jurnal Agribisnis, 3(1), 5770 .

Heriyanto. (2017). Analisis Efisiensi Faktor Produksi Karet Di Kabupaten Kampar Provinsi Riau. https://doi.org/10.5281/ZENODO.122089 8

Heriyanto, H. (2016). Prilaku Konsumsi Pangan Sumber Karbohidrat Rumahtangga Petani Kelapa Sawit di Kecamatan Kandis Kabupaten Siak. Jurnal Ilmiah Pertanian, 13(2), 22-30. https://doi.org/http://doi.org/10.5281/zeno do. 1222080

Kania, R. (2012). Analisis Daya Saing Ekspor Lada Indonesia di Pasar Internasional. Skripsi Fakultas Pertanian, Universitas Siliwangi, Tasikmalaya. (Tidak dipublikasikan).

Kuncoro, M. (2008). Strategi: Bagaimana Meraih Keunggulan Kompetitif? Jakarta: Penerbit Erlangga.

Kusuma, Rahma, L., \& Firdaus, M. (2015). Daya 
Saing Dan Faktor Yang Memengaruhi Volume Ekspor Sayuran Indonesia Terhadap Negara Tujuan Utama. Jurnal Manajemen \& Agribisnis School of Business, 12(3), 226-236. https://doi.org/10.17358/JMA.12.3.226

Nopirin. (1999). Ekonomi Internasional (Tiga). Jakarta: Penerbit BPFE.

Ogi, Suparsa, I. P., \& Martini, Dewi, N. P. (2016). Analisis Daya Saing Ekspor Komoditi Kepiting Provinsi Bali. E-Jurnal Ekonomi Pembangunan Universitas Udayana, 5(6), 652-728.

Prasetio, S., \& Swara, I Wayan, Y. (2015). Analisa Daya Saing dan Faktor-Faktor yang Mempengaruhi Ekspor Kerajinan Rotan Tahun 1993-2012. E-Jurnal Ekonomi Pembangunan Universitas Udayana, 4(6), 608-745.

Rajagukguk, M. . (2009). Analisis Daya Saing Rumput Laut Indonesia di Pasar Internasional. Bogor: Skripsi Fakultas Ekonomi Dan Manajemen, Institut Pertanian Bogor, Bogor (Tidak dipublikasikan).

Ratna Sari, D., \& Tety, E. (2017). Analisis Daya Saing Ekspor Kopi Indonesia Di Pasar Dunia. Jurnal Ilmiah Ekonomi dan Bisnis Universitas Lancang Kuning, 14(1), 20-35.

Salvatore, D. (1997). Ekonomi Internasional (Kelima). Jakarta: Penerbit Erlangga.
Satryana, Made, H., \& Karmini, N. (2016). Analisis Daya Saing Ekspor Teh Indonesia Ke Pasar ASEAN Periode 2004-2013. EJurnal Ekonomi Pembangunan Universitas Udayana, 5(5), 530-651.

Setiawan, K., \& Hartono, Slamet Suryantini, A. (2014). Analisis Daya Saing komoditas kelapa di Kabupaten Kupang. Jurnal Agritec, 34(1), 88-93.

Tambunan, T. (2004). Globalisasi dan Perdagangan Internasional. Bogor: Penerbit Ghalia Indonesia.

Uncomtrade. (2017). Internasional Trade Statistics Database.

Wardanu, A. P., \& Muh, A. (2009). Strategi Pengembangan Agro Indutri Kelapa sebagai upaya percepatan Ekonomi masyarakat di Kabupaten Ketapang. Jurnal Industri, 2(1), 13-29.

Zuhdi, F., \& Suharno, S. (2015). Analisis Daya Saing Ekspor Kopi Indonesia Dan Vietnam Di Pasar ASEAN. E-jurnal Habitat Department of Social Economy, Faculty of Agriculture, 26(3), 152-162. 
